\title{
PENDIDIKAN MULTIKULTURAL DALAM TRADISI PESANTREN DI YOGYAKARTA
}

\author{
Listiyono Santoso \\ UNAIR, Jl. Dharmawangsa Dalam Surabaya, \\ listiyono@fib.unair.ac.id \\ Ilham Nur Alfian \\ UNAIR, Jl. Dharmawangsa Dalam Surabaya, \\ inuralvian@yahoo.com \\ Dewi Meyrasyawati \\ UNAIR, J1. Dharmawangsa Dalam Surabaya, \\ dewi-me-10@fib.unair.ac.id
}

\begin{abstract}
This study discusses the concept of multiculturalism according to the santris and its relation to their religiosity. Santris are those who study at the pesantren, the indigenous form of education in Indonesia. The paper offers a descriptive elaboration of what these santris think of multiculturalism and how they relate it to their belief and religious tradition. It argues that multiculturalism has been the very character of the pesantren in which santris of various cultural background stay to study. How this multiculturalism works and how it influences the santris in the way they look at the idea of nation-hood is the question that needs to be explored. And this paper aims at doing just that. Nation-hood is just another form of multiculturalism. While the santris are used to a life of a multicultural nature, the question of how they adapt to the national culture on the one hand, and how religion shapes the way they behave on the other becomes of particular interest. This paper will show that religion and nationalism are two sides of the same coin - as it were-in the life of the santris.
\end{abstract}

Keywords: Multiculturalism, santris, nationalism, state-hood.

\section{Pendahuluan}

Berbagai kekerasan yang mengatasnamakan agama belakangan ini cukup marak terjadi di negeri ini. Dalam skala yang lebih luas, isu terorisme menjadi perbincangan dominan ketika menyebut kekerasan yang selalu menyertakan agama di dalamnya. Sementara di tempat 
lain, dalam skala yang lebih kecil, berbagai kekerasan atas penganut beragama yang dianggap 'menyempal' dari konstruksi yang sudah ada juga masih sering terjadi. Kasus kekerasan yang menimpa Jamaah Ahmadiyah, aliran Lia Taman Eden, Islam Sejati, dan sebagainya merupakan fakta tentang masih kentalnya kekerasan dijadikan sebagai satu-satunya cara menyelesaikan masalah, termasuk perbedaan keyakinan beragama. Bahkan belum lama di Cianjur, sebuah bangunan peribadatan sebuah agama dihancurkan oleh sekelompok orang dengan alasan dianggap menyalahi ijin pendirian bangunan.

Berbagai fakta kekerasan yang berdimensikan Suku, Agama, dan Ras (SARA) tentu memprihatinkan tidak saja karena dianggap dapat mengganggu dinamika sosial yang sudah ada tetapi juga mencederai realitas keberagaman Indonesia, apalagi jika berbagai kekerasan tersebut sudah mulai melibatkan diskursus keagamaan. Menghubungkan kekerasan dengan ajaran agama cenderung menyederhanakan persoalan. Ada banyak komunitas agama yang kemudian dirugikan oleh berbagai wacana kekerasan yang berdimensikan agama di dalamnya, salah satunya adalah kalangan santri di pondok pesantren.

Dari berbagai kasus kekerasan yang sempat muncul di berbagai media, hampir semua pelaku kekerasan yang mengatasnamakan agama tersebut diberitakan berasal dari kalangan santri dengan kemampuan pengetahuan agama yang cukup baik. Hal ini tentu saja kontraproduktif. Bagaimana mungkin seseorang yang memiliki pengetahuan agama yang baik, ternyata bisa menjadi aktor dalam pelaku kekerasan, meski mengatasnamakan agama. Persoalan penting yang kemudian muncul adalah apakah ideologi keagamaan dapat berpengaruh dalam pemahaman orang atas agama, sekaligus bagaimana mereka mempersepsikan kehadiran orang lain yang berbeda, termasuk berbeda agama.

Upaya untuk meminimalisir aksi kekerasan yang berdimensikan agama menjadi hal yang penting. Tidak saja dalam kepentingan menunjukkan bahwa aksi kekerasan yang dilakukan oleh manusia bukan disebabkan oleh ajaran agama, melainkan oleh kesalahan pemahaman atas agama itu sendiri. Dengan demikian, konstruksi agama yang dibangun dan berhubungan dengan realitas keberagaman di Indonesia menjadi berhubungan secara relevan terhadap lahirnya radikalisasi agama. 
Bagaimanapun, fakta bahwa Indonesia merupakan bangsa yang majemuk tidak hanya dalam etnisitas, kebudayaan tetapi juga dalam hal agama. Bahkan dalam pemahaman atas agama yang sama bisa dipastikan dapat melahirkan pluralitas penafsiran. Realitas kemajemukan bangsa Indonesia menjadi nature dari kondisi kebangsaan ini. Artinya, kondisi kebangsaan Indonesia justru secara alamiah terbangun oleh hadirnya sejumlah SARA yang hidup berdampingan secara damai sebagai bagian penting dari bangsa ini. Karenanya, sebagai sebuah fakta, kemajemukan bangsa Indonesia harus bersinergi dengan bagaimana warga negara memahami dan menerima realitas kemajemukan sebagai keniscayaan sejarah.

Hampir dapat dipastikan, negeri yang terdiri dari ribuan kebudayaan dan ratusan bahasa ini adalah negeri yang 'belum selesai' berproses menjadi sebuah bangsa. ${ }^{1}$ Sebuah bangsa yang di dalamnya hidup berbagai kebudayaan, etnisitas, suku, bahasa dan agama. Realitas keragaman ini menjadi karakteristik bagi negeri ini untuk mengukuhkan identitas kulturalnya sebagai negara bangsa. Sebagai bangsa yang menjadi 'ruang' bagi hidup dan berkembangnya kebersamaan dalam keragaman. Inilah kesadaran multicultural. Kesadaran tidak cukup berbekal pada pengetahuan bahwa masyarakat kita memang masyarakat multikutural. Kesadaran ini menuntut pemahaman mendasar bahwa multikulturalisme adalah keniscayaan keindahan peradaban. Kesadaran ini tidak serta merta dilahirkan, melainkan seharusnya diciptakan melalui berbagai dialog dalam keterbukaan. Faktor pendidikan tampaknya menjadi salah satu alat potensial bagi upaya memberikan kesadaran multikultural bagi masyarakat, termasuk di dalamnya adalah pendidikan di pesantren.

Pesantren sebagai salah satu kekuatan penting dalam pembelajaran dan penyebarluasan ajaran agama (Islam) bukanlah fakta baru. Sejak bertahun-tahun lamanya, bahkan sebelum Indonesia lahir, pesantren telah menjadi tempat pendidikan agama bagi masyarakat Muslim di Indonesia. Hitam putihnya konstruksi pemahaman keagamaan (Islam) di negeri ini tidak bisa dilepaskan dari peran pesantren di dalamnya. Watak ideologi pesantren, juga kiai, sangat berpengaruh terhadap konstruksi santri atas agama dan ruang lingkupnya. Tidak berlebihan, ketika watak ideologi pesantren begitu tekstual dalam memahami agama dan cenderung menganggap bahwa agama sebagai sesuatu yang

${ }^{1}$ Ayu Sutarto dalam Kenedi Nurhan (ed.), Industri Budaya dan Budaya Industri (Jakarta: Kementerian Kebudayan dan Pariwisata RI, 2008), 132. 
sudah selesai, maka apapun konteksnya harus tetap diletakkan pada konstruksi mereka atas teks. Begitu juga ketika pemahaman seperti ini harus dihadapkan dengan fakta multikulturalismenya kebangsaan Indonesia.

Pesantren—dengan demikian—memegang fungsi dakwah penting dalam rangka penyebaran ajaran agama (Islam). Ketika pesantren diletakkan dalam konteks pemahaman keagamaan yang berbasiskan multikulturalisme, maka pesantren selama ini selalu berada di garda terdepan yang dapat merawat pemahaman agama yang sesuai dengan karakter keindonesiaan. Karenanya, menjadikan praktik kekerasan atau juga isu terorisme dengan kalangan pesantren sebagai tertuduhnya harus diuji kembali agar tidak melakukan proses-proses simplifikasi terhadap permasalahan yang terjadi.

Dalam berbagai tradisi keagamaan yang selama dipraktikkan oleh pesantren-pesantren di Indonesia terlihat betapa pemahaman keagamaan para santri sangat akomodatif terhadap lokalitas. Terlebih dalam penerimaan mereka atas realitas multikulturalisme Indonesia. Sebagaimana diketahui sejak bertahun-tahun lamanya, tradisi keagamaan yang dikembangkan kalangan pesantren sangat sesuai dengan kondisi keindonesiaan. Jadi terlalu berlebihan ketika menjadikan pesantren sebagai lembaga yang mengajarkan radikalisasi beragama, terlebih pesantren-pesantren di Yogyakarta.

Kalangan pesantren berkeyakinan penuh bahwa konsepsi kebangsaan Indonesia sudah selesai. Konsepsi kebangsaan Indonesia yang meletakkan realitas multikultural sebagai fakta yang tidak bisa ditolak kehadirannya. Tidak berlebihan jika sebagaimana dikatakan Nur Syam bahwa kebangsaan Indonesia terselamatkan justru karena konstruksi keagamaan yang bersifat inklusif sebagaimana direpresentasikan oleh kalangan pesantren selama ini. ${ }^{2}$

Dalam konteks ini, benar apa yang dikatakan Th. Sumartana bahwa di basis paling dasar dari kehidupan bangsa Indonesia terletak SARA (Suku, Agama, Ras, dan Antargolongan). ${ }^{3}$ SARA adalah biji (seed) atau benih (embrio) yang melahirkan Indonesia. Di mana pun kita mencari identitas asli bangsa ini akan bertemu dengan kenyataan yang berupa kelompok suku, komunitas agama, kepelbagaian ras, dan

2 Nur Syam, Tantangan Multikulturalisme Indonesia: dari Radikalisasi Menuju Kebangsaan (Yogyakarta: Impulse, 2009), 89.

3 Th. Sumartana (ed.), Pluralisme, Konflik dan Pendidikan Agama di Indonesia (Yogyakarta: Interfidei, 2009), 68. 
pluralisme dari golongan-golongan profesi, ideologi, kelas-kelas sosial ekonomi dan lain-lain yang berwarna-warni. Tidak ada yang salah dengan SARA. SARA seungguhnya mengisyaratkan betapa masyarakat hidup tidak dalam bomogenitas (kesamaan), melainkan heterogenitas (keanekaragaman). Kalau terjadi konflik atas SARA, maka kesalahan terletak pada kemampuan negara dan masyarakatnya mengelola SARA secara baik dan benar. ${ }^{4}$

Menurut Nur Syam, setidaknya terdapat tiga hal pola reaksi dalam memahami multikulturalisme, yakni penerimaan, penolakan dan distorsi atau ambivalensi. Penerimaan akan menghasilkan bentuk adaptasi yang positif dari adanya perbedaan kebudayaan dalam masyarakat, penolakan melahirkan sikap radikal dalam menghadapi berbagai perbedaan, sedangkan distorsi biasanya melahirkan sikap ambiguitas dan paradoks dalam memahami realitas multikulturalisme tersebut. Itulah sebabnya, dalam menghadapi berbagai reaksi yang beragam terhadap multikulturalisme, diperlukan suatu bentuk sikap keberagamaan yang akomodatif dan terbuka bagi realitas multikultural dalam masyarakat kita. Pemahaman atas multikulturalisme akan membangun suatu kesadaran dialogis antarperbedaan. Pemahaman yang baik terhadap realitas multikultural ini akan melahirkan suatu sikap terjadinya kesetaraan budaya, kesetaraan pemahaman kebenaran, sehingga antara entitas budaya yang satu dengan lainnya tidak berada di dalam suasana bertanding untuk memenangkan pertarungan. ${ }^{5}$

Dalam konteks inilah, maka penelitian konstruksi para santri tentang multikulturalisme menjadi penting dilakukan. Penelitian ini berupaya mengungkapkan konstruksi agama dan relasi sosial yang dibangun atas semangat multikulturalisme di kalangan santri di Yogyakarta, sekaligus mengetahui proses pembelajaran agama berbasiskan multikulturalisme di beberapa pesantren di Yogyakarta.

\section{Pendidikan Multikultural di Yogyakarta}

Daerah Istimewa Yogyakarta (DIY) lebih dikenal dengan sebutan Yogyakarta. Banyak pihak menyebutkan bahwa keistimewaan Yogyakarta memiliki sejarah panjang sejak era kolonialisme Belanda. Tidak saja karena alasan historis sebagai daerah yang pernah memiliki pemerintahan sendiri, sebagai ibu kota Republik Indonesia, juga

4 Sumartana, Pluralisme, Konflik dan Pendidikan, 68.

${ }^{5}$ Syam, Tantangan Multikulturalisme Indonesia, 71. 
karena alasan sosio kultural yang berbasiskan pada tradisi Jawa kental dengan keraton menjadi pusatnya.

Yogyakarta diakui memang lebih banyak dikenal sebagai kota pendidikan dan kota kebudayaan. Sebagai kota pendidikan dan kota kebudayaan, bukan berarti kota ini tidak memiliki sisi religius. Meski kuat memegang tradisi Jawanya, masyarakat Yogyakarta sesungguhnya merupakan masyarakat yang taat dalam beragama. Kelahiran Muhammadiyah di kota ini sesungguhnya menjadi bukti bahwa masyarakat Yogyakarta adalah masyarakat yang taat beragama. Religiositasnya memang tidak ditunjukkan dengan berbagai ritual massal sebagaimana banyak dilakukan di tempat lain, melainkan dapat dilihat dari sikap beragama mereka yang mengedepankan semangat pluralitas. Meski demikian, Kota Yogyakarta ternyata juga memiliki sejumlah pesantren besar dan berpengaruh yang memberikan kontribusi bagi sikap bergama masyarakatnya. Pesantren-pesantren tersebut tidak hanya bercirikan modern, melainkan juga pesantren salaf (tradisional) yang masih mempertahankan pola pembelajaran klasik.

Meskipun tidak menyandang sebutan sebagai kota santri, di Yogyakarta terdapat banyak pondok pesantren. Sekitar 177 pondok pesantren berdiri di kota ini yang tersebar di 1 kota, 4 kabupaten. Di Kabupaten Bantul terdapat 51 pesantren, Kabupaten Gunungkidul sekitar 21 buah, Kota Yogyakarta terdapat 16 pesantren, Kabupaten Kulonprogo sekitar 33 pesantren, dan Kabupaten Sleman 56 pesantren (Kemenag DIY, 2012). Pesantren-pesantren tersebut dalam banyak hal berafiliasi pada dua organisasi besar Islam, yakni NU dan Muhammadiyah.

Terdapat sejumlah pesantren yang cukup dikenal di kalangan masyarakat yang menjadi tujuan belajar agama para santri dari berbagai daerah. Sebut saja di Kabupaten Bantul seperti PP. AlMahalli Brajan, PP. Al-Fitroh Jejeran, PP. Al-Munawwir, PP. An-Nur, Ngrukem, PP. K.H. Ali Maksum. Pesantren di Kota Yogyakarta yang cukup dikenal adalah PP. Pendidikan Ulama Majlis Tarjih, PP. AlLuqmaniyah, PP. Nurul Ummah Kota Gede, PP. Mu'alimmin Muhamamdiyah. Sedangkan di Kabupaten Sleman, pondok pesantren yang seringkali menjadi tempat tujuan belajar agama adalah PP. Assalimiyyah, Mlangi, PP. Nida'ul Jannah, Mlangi, PP. Wachid Hasyim, Condongcatur, PP. Ki Ageng Giring, Ngaglik, PP. Sunan Pandanaran, Ngaglik, dan masih banyak lainnya. 
Pesantren-pesantren di Yogyakarta tersebut dalam banyak hal memang lebih banyak berada di pinggiran kota Yogyakarta. Pendiri pondok pesantren memang sengaja membangunnya di pinggiran kota dengan tujuan menjaga kota Yogyakarta. Menurut Muhammad Mustafid, ${ }^{6}$ seorang santri di Mlangi mengatakan bahwa pondok pesantren merupakan penjaga moral kebudayaan yang mulai menghantam kehidupan kota. Arus kebudayaan yang begitu kuat masuk di masyarakat, utamanya kota-kota besar sebagai akibat dari gelombang informasi yang masif. Arus kebudayaan itu membawa berbagai bentuk nilai, gaya hidup, dan moralitas baru yang bisa merusak tatanan yang selama ini ada dan tergoyahkan. Kehadiran pesantren dapat menjaga tatanan sosial yang selama ini dimiliki dan sudah cukup melembaga dalam masyarakat. Bahkan ketika arus beragama berbagai kalangan masyarakat, terutama di kota-kota besar, mengalami skripturalisasi dan radikalisasi, maka pondok pesantren memainkan peranan penting untuk membawa pemahaman keagamaan ke perspektif yang lebih humanis dan terbuka.

Pesantren-pesantren di Yogyakarta, sebagaimana pesantren lainnya di Indonesia, sesungguhnya merupakan lembaga pendidikan Islam khas Indonesia. Tidak hanya mampu bertahan dari gempuran modernisasi, pesantren ternyata juga cukup mampu beradaptasi dengan kemajuan zaman, sekaligus menyempurnakan proses pendidikannya tanpa harus kehilangan momentum penjaga moral keagamaan. Dalam sejarahnya, pondok pesantren memiliki peran penting dalam menjaga masyarakat, terutama menanamkan nilai-nilai keagamaan kepada masyarakat. ${ }^{7}$ Itulah sebabnya, pesantren harus dapat memberikan kontribusi bagi masyarakat, terutama memberikan transformasi keagamaan yang lebih baik. Karena khas Indonesia, pesantren selalu bisa beradaptasi dengan lingkungan sekitar, sekaligus menjaga dan merawat tradisi masyarakat setempat.

Penelitian ini mengambil data di sejumlah pesantren yang lebih banyak berafiliasi pada Nahdlatul Ulama (NU), bukan pada pesantrenpesantren modern yang banyak berdiri di tengah-tengah kota. Afiliasi pesantren tersebut memang tidak ditunjukkan secara ekplisit dan terbuka. Peneliti hanya mendekatinya dengan keterlibatan aktif pimpinan pesantren dan sejumlah santrinya pada organisasi NU

${ }^{6}$ Muhammad Mustafid, Wawancara, Yogyakarta, 10 Agustus 2012.

7 Zamakhsyari Dhofier, Tradisi Pesantren: Studi tentang Pandangan Hidup Santri (Jakarta: LP3ES, 1982), 13. 
maupun badan otonomnya. Keterlibatan sejumlah pimpinan pesantren dan para santri tersebut tidak hanya dalam ormas sosial tetapi juga ada yang terlibat sebagai pengurus Forum Kerukunan Umat Beragama (FKUB) di Yogyakarta, seperti K.H. Ahmad Muhaimin salah satu pengasuh PP. Nurul Ummah, Kotagede, K.H. Salimi dari PP. Assalimiyyah, K.H. Barmawi dari PP. Ploso Kuning, dan sebagainya.

K.H. Ahmad Muhaimin ${ }^{8}$, pimpinan Pondok Pesantren Nurul Ummah Kotagede, mengatakan bahwa pada dasarnya pesantrenpesantren di Yogyakarta tidak berbeda dengan pesantren lainnya di Jawa. Mayoritas para pengasuhnya berasal dan belajar dari pesantrenpesantren besar di Jawa, utamanya Jawa Timur seperti PP. Tebuireng, PP. Lirboyo Kediri, dan PP. Denanyar Jombang. Kesamaan tempat belajar membuat tipikal pesantrennya tidak berbeda. Hampir semua pesantren di Yogyakarta merupakan pesantren salaf ${ }^{9}$, kecuali beberapa pesantren modern yang berada di kota Yogyakarta yang bersifat netral atau berada dalam satu yayasan tertentu. Sebagai pesantren salaf, pesantren di Yogyakarta memang cukup inklusif dalam menerima pemikiran dan tradisi yang berangkat dari kondisi lokal. Inklusivitas itu biasanya dapat dilihat dari sikap dan perilaku keberagamaan para santrinya yang menghargai keragaman pemikiran.

Pemahaman keagamaan-dengan demikian-berhubungan dengan sikap dan perilaku beragama masyarakat, terutama masyarakat santri. Afiliasi pesantren menentukan bagaimana konstruksi keberagamaan terbentuk. Dalam banyak hal, pesantren-pesantren di Yogyakarta adalah pesantren yang akrab dengan dialog kebangsaan dan multikulturalisme. Di PP. Sunan Pandanaran, Ngaglik, Sleman pimpinan K.H. Mu'tashim Billah putra dari K.H. Mufid Mas'ud terdapat sejumlah santri yang bergiat dalam Forum Gusdurian. Sebuah forum yang didirikan oleh sejumlah aktivis muda pesantren yang mencoba meneruskan gagasan-gagasan Gus Dur (Abdurahman Wahid, alm.) tentang agama, kemanusiaan, dan kebangsaan. Membaca namanya saja (Forum Gusdurian) sangat jelas orientasi gerakan dari forum tersebut yang menggunakan nama besar Gus Dur sebagai Bapak Pluralitas Bangsa. Semangat yang kuat untuk mendialogkan

8 Ahmad Muhaimin, Wawancara, Yogyakarta, 11 Agustus 2012.

9 Suatu istilah untuk menyebut sebagai pesantren yang masih tradisional dengan pola pengajaran pendidikan Islam klasik seperti sorogan dan bandongan kitab kuning, dan biasanya berada dalam jami'iyyah Nahdliyin (NU) 
agama (Islam) dengan wawasan kemanusiaan dan kebangsaan menjadi ciri yang melekat kuat dalam forum tersebut.

Kharisma kasultanan disertai dengan kekuatan simbolitas keraton juga turut serta membentuk pola pembelajaran pesantren di Yogyakarta untuk mengakomodir tradisi dan kebudayaan lokal. Pesantren-pesantren di Yogyakarta tampaknya menyadari betul posisinya sebagai bagian integral dari wilayah Yogyakarta yang menjadikan Kasultanan dengan Sultan HB sebagai pemimpin kultural yang merekatkan solidaritas warga Yogyakarta. Kekuatan kebudayaan melalui berbagai tradisi Jawa yang kental berfungsi sebagai media perekat sosial bagi warga Yogyakarta, yang berbeda-beda agama, etnisitas, dan stratifikasi sosial. Radikalisasi agama yang mencoba merusak hubungan antarumat beragama seolah dianggap mencederai rumah kebudayaan yang dimiliki masyarakat Yogyakarta tersebut. Sikap inklusif terhadap tradisi-tradisi lokal bukan karena keberadaan mereka di lingkungan yang bertradisi Jawa cukup kental. Pengaruh budaya keraton dengan kehadiran kepemimpinan Sri Sultan HB ke IX maupun $\mathrm{X}$ yang kharismatik membuat pesantren-pesantren di Yogyakarta lebih didominasi pola pengajaran keislaman yang terbuka dan akrab dengan kebudayaan-kebudayaan setempat.

Pondok pesantren di Yogyakarta yang berafiliasi pada organisasi NU baik secara ekplisit maupun implisit, selama ini, dikenal aktif mendorong terjadinya dialog agama dan kebangsaan. Pengajaran pendidikan agama Islam kepada santri tidak dilepaskan dalam konteks keindonesiaan. Dialektika yang demikian menjadikan para santri kemudian memiliki ruang dialog yang terbuka untuk mengembangkan pemahaman keagamaannya dalam konteks realitas sosial. Itulah sebabnya, ada banyak forum-forum dialog agama dan kebangsaan yang terlahir dari lingkungan pesantren ini. Begitu pula ada banyak pemikir muda lahir dari pesantren yang terlibat aktif mendorong terjadinya dialog multikultural dengan semangat kebangsaan tinggi.

Yang menarik dan cukup berpengaruh dalam realitas sosial keberagamaan adalah aspek sosio-kultural yang membentuk masyarakat Yogyakarta. Berbagai macam komunitas sosial tumbuh dan subur membentuk keanekaragaman yang menghiasi Yogyakarta sebagai masyarakat yang heterogen, baik dari segi agama, etnisitas, pendidikan maupun stratifikasi sosial lainnya. Kultur Jawa yang sinkretis dan toleran menjadi media perekat sosial dari keberagaman yang tumbuh di dalamnya. Suasana yang demikian memang tidak 
dapat dilepaskan dari keberadaan kasultanan Ngayogyakarta yang dalam banyak hal turut membantu terjadinya proses pembentukan masyarakat yang multikultural ini. Dalam konteks yang demikian, maka posisi sultan dalam gerak kultural masyarakat menjadi bandul penjaga keselarasan, harmoni dan terjalinnya keseimbangan sosial di dalam masyarakat yang sedang mengalami perubahan. ${ }^{10}$

Posisi kasultanan yang masih cukup kharismatik di hadapan publik Yogyakarta memberikan kontribusi penting bagi penjagaan tatanan sosial yang heterogen ini untuk berada dalam satu rajutan. Kasultanan menjadi penjaga gawang kebudayaan yang mengedepankan harmonisasi sosial yang mengayomi. Sultan itu menjadi simbol perekat kultural warga Yogyakarta yang berbeda-beda agama, status sosial, maupun latar pendidikan. Tidak heran ketika terjadi berbagai kerusuhan berdimensikan SARA pasca reformasi 1997, seperti Jakarta, Ambon, Sampit, Poso, dan sebagainya tidak merembet masuk di kota ini. Meskipun harus diakui bahwa dalam masa transisi, kota ini pernah dihadapkan dengan adanya berbagai macam provokasi yang bertujuan menciptakan abnormalitas di dalam masyarakat, salah satu di antaranya adalah adanya penghadiran sensitivitas-psikologis konflik 'agama' di Ambon maupun Poso.

Mengapa Yogyakarta tidak mudah terbawa dalam perilaku kekerasan maupun radikalisasi beragama, khususnya menyangkut isu agama? Dalam sebuah riset yang dilakukan oleh Abdul Rozaki mengatakan bahwa dilihat dari perspektif sosio-kultural masyarakat Jawa, yang biasanya menempatkan agama bukan sebagai isme sosial atau sesuatu yang bersifat ideologis. Agama dijadikan sebagai bagian dari wilayah yang bersifat personal-pribadi. Bagi kebanyakan orang Yogyakarta, keimanan kemudian tidak dibelenggu oleh sebuah institusi keberagamaan. Apapun agamanya, ketaatan sebagai orang Jawa masih cukup kental. Hal ini dapat dilihat dari kebiasaan di kalangan orang Jawa dalam melakukan pengembaraan spiritual untuk mencapai realitas (hakikat) dari Tuhan YME. Bentuk penziarahan spiritual dilakukan dengan berbagai cara, dari berguru ke berbagai tempat, melakukan pertapaan dan bersemedi, sembahyang, wiridan bagi yang beragama Islam, maupun proses sosio-kultural lainnya. ${ }^{11}$

${ }^{10}$ Imam Baihaqi (ed.), Agama dan Relasi Sosial: Menggali Kearifan Dialog (Yogyakarta: LKiS, 2002), 92.

${ }^{11}$ Ibid., 94.

132 ISLAMiCA, Volume 7, NOMOR 1, SEPTEMBer 2012 
Namun demikian, harus diakui bahwa realitas keberagamaan masyarakat Yogyakarta adalah realitas yang menghargai keragaman. Perbedaan pemahaman keyakinan bukanlah alasan untuk tidak membangun solidaritas dan soliditas bersama. Penelitian yang diselenggarakan Imam Baehaqi tentang hubungan antaragama di Yogyakarta menemukan suatu fakta menarik. Menurutnya, masyarakat Yogyakarta sesungguhnya adalah masyarakat yang terbiasa hidup dalam suasana harmonisasi sosial tinggi. Kehidupan harmonis menjadi tujuan dalam setiap pengelolaan kehidupan. Karenanya, perbedaan agama, perbedaan kebudayaan, berbeda etnisitas, dan perbedaan lainnya justru dikelola agar diarahkan kepada keadaan yang harmonis tadi. Adanya perbedaan dalam beragama, misalnya, yang ditemukan di kalangan keluarga masyarakat Yogyakarta setidaknya menanamkan benih dasar dari adanya sikap toleran dan penghargaan atas perbedaan pandangan menyangkut keimanan. ${ }^{12}$ Semangat toleransi dan penghormatan terhadap pluralisme sosial nampak menonjol dalam sikap keberagamaan masyarakat di Yogyakarta, terlebih para santri yang memiliki dasar pengetahuan keagamaan yang baik.

Pada dasarnya, fenomena semangat keberagaman dalam sikap beragama masyarakat Yogyakarta dapat dilacak pada sistem nilai yang membentuk pola pikiran, penghayatan dan pandangan hidup masyarakatnya. Suatu tindakan tidak dapat berdiri sendiri, keberadaannya saling terkait erat dengan dinamika sosial masyarakat yang membentuk pengalaman kolektif yang terinternalisasi dalam kehidupan praksis dalam waktu yang lama, sehingga menciptakan identitas tersendiri sebagai bagian dari fenomena budaya masyarakat. ${ }^{13}$ Sebagaimana diketahui, sikap batin orang Jawa terhadap agama, termasuk masyarakat Yogyakarta, adalah bukanlah terletak pada kebenaran suatu 'agama', melainkan bagaimana praktik beragama semakin membuatnya menjadi manusia yang lebih baik. Kebenaran suatu agama bagi sikap batin orang Jawa lebih diletakkan pada apakah pandangan dunia tersebut cocok dengan pengalaman. Artinya dapat dirasakan sebagai sesuatu yang bermakna atau tidak. ${ }^{14}$

\footnotetext{
12 Ibid., 110-112.

13 Peter L. Berger, Langit Suci: Agama sebagai Realitas Sosial (Jakarta: LP3ES, 1994), 38.

14 Niles Mulder, Kebatinan dan Hidup Sehari-hari Orang Jawa (Jakarta: Gramedia, 1984), 11.
} 
Beragama, dengan demikian, bagi pendapat para santri (yang diwawancarai) seharusnya membuat kehidupan pribadi dan sosial menjadi lebih baik dari sebelumnya. Hal ini seolah menggambarkan suatu perspektif universal atas kebenaran agama. Arif Fauzi Marzuki ${ }^{15}$ (36 tahun), seorang santri yang pernah belajar di Pesantren Krapyak, mengatakan yang penting bukan apa agamanya, melainkan bagaimana cara beragama. Baginya, pesantren tempatnya belajar selama ini memberikan pola pendidikan yang menghargai perbedaan keyakinan agama. Ia diajarkan memiliki keteguhan pemahaman keagamaan tanpa harus menegasikan keyakinan keagamaan lainnya. Kebenaran keyakinan keagamaan yang dimilikinya tidak kemudian mengharuskannya memberikan stigma sesat kepada keyakinan agama lain.

Keyakinan kebenaran Islam sudah sangat jelas diterangkan dalam kitab Suci al-Qur'ân. Tetapi, bagaimana harus bersikap dalam kehidupan sosial jelas membutuhkan suatu pemahaman yang terbuka atas adanya perbedaan yang ada. Tidak bisa dipaksakan bahwa keyakinan itu bersifat tunggal. Semuanya hadir di depan mata kita, tanpa bisa ditolak. Yang dibutuhkan sekarang adalah bagaimana berkeyakinan atas agama masing-masing itu saling menjaga perasaan atas keyakinan yang berbeda. ${ }^{16}$

Memang pemahaman keberagamaan para santri tidak bisa dijadikan sebagai representasi keberagamaan masyarakat Yogyakarta pada umumnya. Realitas keberagamaan masyarakat Yogyakarta yang diungkapkan para santri dapat memberikan suatu gambaran umum tentang bagaimana pola pembelajaran keagamaan di berbagai pesantren yang menjadi objek penelitian ini. Konstruksi keberagamaan terbentuk melalui proses belajar yang panjang, dari interaksi antara kiai dengan pesantren, antara santri dengan santri dan dialektika mereka dengan lingkungan Yogyakarta yang kondusif bagi tumbuh kembangnya pemahaman keagamaan yang inklusif dan mengedepankan relasi sosial.

Dinamika keberagamaan di Yogyakarta-disadari atau tidakcukup dinamis dan tidak pernah menunjukkan fenomena konfliktual. Dinamikanya dapat diperhatikan dari hadirnya sejumlah komunitas beragama, baik internal dalam agama maupun dialog antarumat beragama. Dalam konteks kerukunan umat beragama, kehadiran

\footnotetext{
15 Arif Fauzi Marzuki, Wawancara, Yogyakarta, 1 September 2012.
}

16 Ibid. 
FKUB di Yogyakarta yang cukup intensif menggelar berbagai forum dan kegiatan yang mendorong kebersamaan, munculnya DIAN (Dialog Antar-Iman) yang dimotori sejumlah aktivis dari berbagai agama, serta banyaknya kalangan intektual yang berbasis masingmasing agama, dari akademisi, kiai, pastur, biksu hingga pendeta yang memiliki pemahaman keagamaan yang berwawasan pluralitas. Keberadaan pesantren, tempat-tempat ibadah yang menjadi ruang dialog, lembaga pendidikan tinggi yang ternama baik umum maupun berbasis agama, dan organisasi massa semakin memperkuat basis keyakinan keberagamaan masyarakat Yogyakarta.

Realitas keberagamaan yang demikian, dengan ciri keterbukaan yang menerima berbagai perbedaan, mendapatkan basis kultural dari kondisi masyarakat Yogyakarta. Sebagaimana dijelaskan sebelumnya, kekuatan tradisi itu justru menciptakan solidaritas sebagai warga Yogyakarta. Ikatan ini, meski bersifat emosionalitas, menjadi media perekat satu sama lain. Keinginan yang kuat agar Yogyakarta menjadi ruang yang nyaman bagi tumbuhnya realitas keberagamaan yang pluralis akhirnya mampu menjaga keutuhan tatanan sosial meski tetap menjaga adanya perbedaan masing-masing. Pada konteks ini, maka perlu konstruksi ulang sikap negatif atas kehadiran tradisi dari penganut agama yang bisa kontra produktif bagi keutuhan tatanan sosial. Meskipun demikian, sikap akomodatif tidak kemudian mencampuradukkan ajaran satu sama lain. Kemampuan menjaga dan merawat tradisi lokal (baca: Jawa dalam konteks penelitian ini) tidak lagi dianggap sebagai sikap sinkretis dalam beragama, melainkan suatu sikap yang terbuka bahwa keislaman dan kejawaan adalah dua entitas yang bisa bersinergi.

Dalam konteks masyarakat Yogyakarta, kekuatan tradisi Jawa yang mengedepankan harmonisasi sosial menjadi media perekat bagi realitas perbedaan tersebut. Hal ini diyakini karena kentalnya tradisi Jawa, apalagi ada kasultanan Yogyakarta yang menjadi simbol kebudayaan warga Yogyakarta telah memberikan kearifan lokal untuk memelihara tatanan yang multikultural. Baginya, keragaman kebudayaan di Indonesia harus dapat diterima secara positif bagi setiap orang Islam. Penerimaan atas keragaman dapat membangun sikap dialogis setiap terjadinya potensi benturan sebagai akibat dari adanya keragaman tersebut. Tanpa ada pemahaman yang positif bagi realitas multikultural di Indonesia, maka benturan kebudayaan mudah sekali terjadi. 


\section{Penutup}

Konstruksi para santri di Yogyakarta, terutama dalam lingkungan pesantren yang berafiliasi pada NU, menunjukkan sikap positif dalam menerima multikulturalisme. Realitas masyarakat yang beragam dipahami sebagai keniscayaan sejarah yang harus diterima tanpa harus dikonfrontir dengan keyakinan beragama mereka. Multikulturalisme dipahami sebagai adanya realitas bahwa masyarakat Indonesia adalah masyarakat yang sejak kelahirannya berawal dari keragaman kebudayaan, perbedaan keyakinan, dan etnisitas yang berbeda-beda.

Penerimaan atas berbagai perbedaan kebudayaan dan keyakinan adalah cerminan dari sikap keagamaan yang inklusif. Sikap tersebut terbentuk melalui proses panjang dalam pengalaman empiris mereka, baik ketika berada dalam pesantren maupun berada dalam kehidupan sosial di masyarakat. Sikap akomodatif terhadap tradisi Jawa yang tumbuh dan berkembang dalam masyarakat Yogyakarta menjadi representasi betapa kesadaran atas multikulturalisme terinternalisasi dalam keberagamaan para santri.

Bagi para santri, hidup di tengah kota Yogyakarta yang kental dengan tradisi Jawanya, apalagi di dalamnya terdapat kasultanan sebagai simbol kultural warga Yogyakarta, diperlukan suatu sikap terbuka menerima setiap bentuk perbedaan yang ada. Keterbukaan tersebut tidak mengurangi keyakinan para santri terhadap kebenaran agamanya, melainkan semakin terlembagakan. Justru karena penerimaan inilah nilai-nilai tradisi Jawa menjadi media perekat sosial bagi terciptanya tatanan sosial yang dinamis dan harmonis. Tidak heran jika penerimaan ini menjadikan dinamika kehidupan beragama (Islam) pada masyarakat santri selalu dapat berdialektika dengan perkembangan zaman.

Konstruksi para santri tentang multikulturalisme terbentuk melalui model pembelajaran agama yang berwawasan kebangsaan. Lingkungan pesantren juga cukup mempengaruhi munculnya sikap positif para santri dalam memaknai multikulturalisme di Indonesia. Sikap ini mampu menciptakan suatu dialog kerukunan antarumat beragama, sekaligus dialog antaragama dan kebudayaan. Sikap positif dan terbuka ini penting karena memberikan dampak bagi bagaimana mendialogkan agama dengan realitas sosial yang beragam. Dalam konteks ini, maka lahirlah suatu sikap bahwa yang terpenting bukan di mana letak kebenaran agama, melainkan bagaimana cara beragama, semakin membuat kualitas masyarakat menjadi lebih baik dan 
bermartabat. Itulah sebabnya, model pembelajaran agama yang mengedepankan wawasan kebangsaan diselenggarakan. Suatu bentuk pendidikan keagamaan yang terbuka dan akomodatif terhadap realitas multikulturalisme memberikan pengaruh positif bagi sikap dan penerimaan para santri terhadap fakta adanya keragaman di Indonesia. Pendidikan keagamaan yang bersifat doktriner dan formalistik cenderung tertutup dan semakin memberikan kecenderungan menguatnya sikap radikal dalam beragama.

Pola pendidikan keagamaan yang berwawasan kebangsaan pesantren di Yogyakarta, terutama yang berafiliasi dengan organisasi NU, diselenggarakan melalui pendidikan multikultural yang memberikan kepada santri pengetahuan dan praktik hidup yang mengajarkan nilai kebenaran dan kemanusiaan yang dicontohnya melalui pesan profetik kenabian, atau memberikan narasi para tokohtokoh besar yang memberikan inspirasi bagi pentingnya nilai kemanusiaan sebagai edukasi sosial. Proses pembelajaran yang demikian tidak hanya menawarkan ajaran keselamatan pada masingmasing agama, melainkan bagaimana para santri dalam menjelaskan posisi mereka di tengah keragaman agama dan kebudayaan ini.

\section{Daftar Rujukan}

Baihaqi, Imam (ed.). Agama dan Relasi Sosial: Menggali Kearifan Dialog. Yogyakarta: LKiS, 2002.

Berger, Peter L. Langit Suci: Agama sebagai Realitas Sosial. Jakarta: LP3ES, 1994.

Dhofier, Zamakhsyari. Tradisi Pesantren: Studi tentang Pandangan Hidup Santri. Jakarta: LP3ES, 1982.

Marzuki, Arif Fauzi. Wawancara. Yogyakarta, 1 September 2012.

Muhaimin, Ahmad. Wawancara. Yogyakarta, 11 Agustus 2012.

Mulder, Niles. Kebatinan dan Hidup Sehari-hari Orang Jawa. Jakarta: Gramedia, 1984.

Mustafid, Muhammad. Wawancara. Yogyakarta, 10 Agustus 2012.

Sumartana, Th. (ed.). Pluralisme, Konflik dan Pendidikan Agama di Indonesia. Yogyakarta: Interfidei, 2009.

Sutarto, Ayu dalam Nurhan, Kenedi (ed.). Industri Budaya dan Budaya Industri. Jakarta: Kementerian Kebudayan dan Pariwisata RI, 2008.

Syam, Nur. Tantangan Multikulturalisme Indonesia: dari Radikalisasi Menuju Kebangsaan. Yogyakarta: Impulse, 2009. 